\title{
Evaluation of Surface Milling Strategies Using Selected Elements of Machined Shapes of Forging Die Cavities
}

\author{
Peter Izol $^{1}$, Michal Fabian ${ }^{1}$, Melichar Kopas ${ }^{1}$, Gabriel Fedorko $^{2}$, Jana Fabianova ${ }^{3}$ \\ ${ }^{1)}$ Faculty of Mechanical Engineering, Technical University of Košice, Letná 9, Košice, 040 01, Slovakia. \\ peter.izol@tuke.sk,michal.fabian@tuke.sk,melichar.kopas@tuke.sk \\ ${ }^{2)}$ Logistic institute of industry and transport, Faculty BERG, Technical University of Košice, Park Komenského 14, Ko- \\ šice, 040 01, Slovakia.gabriel.fedorko@tuke.sk \\ 3) University of Security Management in Kosice, Kostova 1, Kosice, 040 01, jana.fabianova@vsbm.sk
}

The shaping tools or shaping moulds are applied in such production processes like forging, pressing, casting or injection moulding. These technological processes are described by Groover in [1] and Kalpakjian in [2], as well as in the other professional works, e.g. in $[3,4,5]$. A quality of the shaping tools influences also quality of the produced components. This fact is an important aspect in the framework of the whole production chain. The shaping tools and moulds are expensive. An important role is playing the selected production technology of the given shaping tool. If there are applied machining technologies specified for production of the shaping tool, it is necessary to take into consideration also the suitable machining strategies for such technological operation. The term "machining strategy" represents a pre-definition of such tool trajectory in the CAM-system, which is optimised for machining of the various shaped surfaces in order to produce the final product with the highest possible efficiency.[5]

Keywords: surface milling, shaping tools, CAM

\section{Acknowledgements}

This paper was elaborated with support of the grant project VEGA 1/0500/12, VEGA 1/0356/11, 1/0922/12 and 1/0036/12.

\section{References}

[1] GROOVER, M.P. (2010). Fundamentals of Modern Manufacturing: Materials, Processes, and Systems. John Wiley \& Sons, New York.

[2] KALPAKJIAN, S. (1989). Manufacturing engineering and technology. Addison-Wesley, Wokingham.

[3] ALTAN, T., LILLY, B., YEN, Y.C. (2001). Manufacturing of Dies and Molds. In: CIRP Annals - Manufacturing Technology, Vol. 2001, No. 50, pp. 404-422, ISSN: 0007-8506.

[4] FABIANOVÁ, J. (2006). CAD/CAM systémy pri návrhu tvaru a výrobe plastových výliskov. In: Transfer Inovácií, Vol. 2006, No. 9, pp. 88-90, ISSN: 1337-7094.

[5] MAWUSSI, K.B., TAPIE, L. (2011). A knowledge base model for complex forging die machining. In: Computers \& Industrial Engineering, Vol. 61, No. 1, pp. 84-97, ISSN: 0360-8352.

[6] FABIAN, M., SPIŠÁK, E., ŠEMINSKÝ, J., DOVICA, M., IŽOL, P. (2010). CAM parameters setup and milled concave and covex surface quality. In: Metalurgija, No. 2, pp. 181-185, ISSN 0543- 5846.

[7] MICHALIK, P., ZAJAC, J., DUPLÁK, J., PIVOVARNÍK, A. (2012). CAM Software Products for Creation of Program for CNC Machining. In: Future Communication, Computing, Control and Management, Vol. 141, pp. 421-425, ISBN: 978-3-642-27310-0.

[8] MOLNÁR, V., TÖRÖK, Cs., LAVRIN, A., DRUTAROVSKÝ, M., REPEJ, V. Identification of parameters and deviations real Pascal's scroll with harmonic analysis. Proceedings of 4. International DAAAM Symposium, VUT Brno, 1993: pp. 195-196.

[9] CHEN, Z. C., SONG, D. (2006). A Practical Approach to Generating Accurate Iso-Cusped Tool Paths for ThreeAxis CNC Milling of Sculptured Surface Parts. In: Journal of Manufacturing Processes, Vol. 8, No. 1, pp. 29-38, ISSN: 1526-6125.

[10] IŽOL, P., ĎURÍČEK, M. (2010). CAM systémy a hodnocení strategií obrábění. In: itCAD, Vol. 20, No. 6, pp. 3233, ISSN: 1802-0011.

[11] DOVICA, M., GMITERKO, A., MOLNÁR, V. (1995). Gauge for straightness and perpendicularity measurement. Proceedings of the International Computer Science Conference MicroCAD '95, Miskolc, pp. 1-4. 
[12] YAO, Z., GUPTA, S. K. (2004). Cutter path generation for 2.5D milling by combining multiple different cutter path patterns. In: International Journal of Production Research, Vol. 42, No. 11, pp. 2141-2161 ISSN: 00207543.

[13] SPIŠÁK, E., KMEC, J., BREZINOVÁ, J., GUZANOVÁ, A., MAJERNÍKOVÁ, J. (2012). Materiály pre konvenčné a progresívne technológie. Technical University of Košice.

[14] RAMOS, A. M. RELVAS, C. SIMOES, J. A. (2003). The influence of finishing milling strategies on texture, roughness and dimensional deviations on the machining of complex surfaces. In: Journal of Materials Processing Technology, Vol. 136, No. 1-3, pp. 209-216, ISSN: 0924-0136.

[15] TOH, C. K. (2005). Design, evaluation and optimisation of cutter path strategies when high speed machining hardened mould and die materials. In: Materials \& Design, Vol. 26, No. 6, pp. 517-533, ISSN: 0261-3069.

[16] TOH, C. K. (2004). A study of the effects of cutter path strategies and orientations in milling. In: Journal of Materials Processing Technology, Vol. 152, No. 3, pp. 346-356, ISSN: 0924-0136.

[17] COLEMAN, G. (2005). A new tool path strategy taps the true potential of CNC milling Machines. In: $C N C M a-$ chining, Vol. 9, No. 33, pp. 20-25.

[18] TOMÁŠ, M., IŽOL, P., DRAGANOVSKÁ, D., BEŇO, J. (2012). CAD modeling of active surfaces in design of dies. In: Scientific Bulletin of the „Petru Maior” University of Tîrgu Mureş, Vol. 2012, No. 9, pp. 44-49.

[19] MACUROVÁ, A., VASILKO, K. (2012). Two local extremes of cutting speed. In: Manufacturing Technology, Vol. 12, pp. 86-89, ISSN 1213-2489.

[20] MÁDL, J. (2012). Surface Properties in Precise and Hard Machining. In: Manufacturing Technology, Vol. 12, No. 13, pp. 158-166, ISSN 1213-2489. 